\title{
In-vitro Evaluation of Thymol Derived from Trachyspermum ammi Against Acetaminophen Induced Hepatotoxicity Towards Lymphatic Filariasis Therapeutics
}

\author{
Abel Arul Nathan and Anand Setty Balakrishnan \\ Department of Genetic Engineering, School of Biotechnology, Madurai Kamaraj University, Madurai -625021, India
}

*Corresponding author: Anand Setty Balakrishnan, Department of Genetic Engineering, School of Biotechnology, Madurai Kamaraj University, Madurai -625021, India, Tel: +91 - 9840212555; E-mail: settyanand@gmail.com

Received date: August 10, 2017; Accepted date: October 06, 2017; Published date: October 10, 2017

Copyright: (C) 2017 Nathan AA, et al. This is an open-access article distributed under the terms of the creative commons attribution license, which permits unrestricted use, distribution, and reproduction in any medium, provided the original author and source are credited.

\begin{abstract}
Individuals with lymphatic filariasis (LF) shows elevated levels of pro-inflammatory cytokines, altered expressions of inflammatory genes and are prone to secondary bacterial infection. Also markers of liver dysfunction were reported to be high with increased filarial infection. Acetaminophen (Paracetamol), an anti-pyretic drug was prescribed to LF individuals along with Diethylcarbamazine and Albendazole to alleviate pain and filarial fever within the therapeutic dosage. It is unclear, whether parasite secreted toxins augments the action of acetaminophen and enhances liver dysfunction. Hence, an agent which can attenuate the acetaminophen toxicity during filarial infection is warranted. Trachyspermum ammi $(T$. ammi) is the richest source of thymol, reported to have anti-filarial lead molecule. In the present study we evaluated the effects of thymol against acetaminophen induced hepatotoxicity in in-vitro settings. In addition, we examined the synergistic effects of thymol against bacterial infection, free radicals and cytokine production. Our results reveal that acetaminophen induces significant reduction in the viability of WRL-68 liver cells compared to cells without treatment. However, thymol at the same concentration restores the cell viability significantly $(p=0.031)$ by attenuating the toxicity within $24 \mathrm{~h}$. Thymol inhibits the expression of Interleukin- 6 $(p=0.043)$ and Interleukin-8 $(p=0.048)$ in WRL-68 cells and thereby augments maximum protection to liver cells from inflammatory insults. Calorimetric analysis shows the ability of thymol in scavenging hydrazyl $(p=0.004)$ and hydrogen peroxide $(p=0.008)$ free radicals efficiently. Thus thymol derived from $T$. ammi may be a good therapeutic agent in reducing the toxicity of acetaminophen, may also aids in LF treatment and management in addition to the existing drugs.
\end{abstract}

Keywords: Thymol; Trachyspermum ammi; Acetaminophen; Hepatotoxicity; Lymphatic filariasis

\section{Introduction}

Lymphatic filariasis (LF) is a major parasitic infection caused by nematodes such as Brugia malayi and Wuchereria bancrofti. These parasites dwell in the lymphatic vessels and eventually lead to chronic lymphedema and elephantiasis [1]. Stagnation of lymph fluid encourages secondary bacterial and fungal infection on the dermal cells and tissues. Bacterial growth, multiple skin lesions, attenuates lymph movement and the reduced ability of the lymph nodes to filter the bacteria leads to inflammation. Recurrent episodes of bacterial infections further damage the tiny lymphatic vessels in the skin, reducing their ability to drain fluid efficiently. Nevertheless LF is associated with the elevated levels of pro-inflammatory and profibrotic cytokines [2]. Notably, the expression of genes involved in cellular adhesion, inflammation and lymphangiogenesis were altered. All these pathophysiological stimuli promote the progression of lymphedema from reversible to irreversible state [3].

DEC and ALB are the promising microfilaricidal drugs, least effective against microfilaria [4]. Paracetamol, a commonly used analgesic and anti-pyretic drug was given frequently to alleviate parasite induced pain and filarial fever to the LF individuals within the therapeutic dose. The drug was considered to be safe, when taken within therapeutic dose but the higher dose leads to liver damage and acute liver failure $[5,6]$. Pumford et al., reported that increased levels of Alanine Transaminase (ALT) and Aspartate Transaminase (AST) in serum, directly correlates with the appearance and formation of paracetamol-cytotoxic protein adducts, which is said to be a biomarker indicating the paracetamol toxicity [7]. Jaeschke et al. reported the plausible mechanisms pertaining to hepatotoxicity imparted by bile acids, adhesion molecules, cytochrome enzyme, peroxy-nitrite and mitochondrial dysfunction [8].

India has rich resource of medicinal herbs and aromatic spices with high potential abilities, needed to be studied for their medicinal applications. Accumulated research reports highlights the beneficial and therapeutic role of Trachyspermum ammi [9,10]; however, research studies addressing the influence of thymol derived from $T$. ammi are necessary in understanding the mode of disease suppression. Existing data support the involvement of pro-inflammatory cytokines namely Interleukin-6 (IL-6) and Interleukin-8 (IL-8) were significantly elevated in LF [2], which plays a key role in the initiation of irreversible swelling, fibrosis [11,12] and regenerative processes of hepatic structure and function $[13,14]$. Hence, we investigated the potential abilities of thymol against hepatotoxicity, bacterial infection; oxidative stress, elevated cytokines and inflammatory markers expression in response to paracetamol induced effects in WRL-68 liver cells. The study warrants insights in addressing the strategies for lymphatic filarial treatment and management. 


\section{Materials and Methods}

\section{Materials}

HPLC grade Methanol (Cat: AS059), Hexane (Cat: AS097), Chloroform (Cat: AS114), Glacial acetic acid (Cat: AS001) and Microbiological grade, Mueller Hinton agar (Cat: M173) were purchased from Himedia. Molecular grade reagents required for RNA isolation namely TRI reagent (Cat: T9424), Chloroform (Cat: V800116), Isopropanol (Cat: V800228), Formaldehyde (Cat: V800189), MOPS (Cat: M1254), DEPC (Cat: D5758), Thymol (Cat: T0501) and MTT reagent (Cat: M2128) were purchased from Sigma Aldrich. LDH Cytotoxicity Assay Kit (BioVision, Cat: K311-400), Acridine Orange (Cat: A6014), Propidium Iodide (Cat: P4864) and all qRT-PCR primers were purchased from Sigma Aldrich. Fetal Bovine Serum (Gibco, Cat: 10270), DMEM (Cat: SH30243.01), Antibiotic Anti-mycotic Solution (Cat: A002) and Trypsin-EDTA (Himedia Labs, Cat: TCL007).

\section{Plant extraction and phytochemical evaluation}

Seeds of T. ammi were collected from local market in Madurai, identified by a botanist and voucher specimen was kept for future studies. The seeds were rendered free from all impurities by washing with distilled water, shade dried and grinded into fine powder. About $100 \mathrm{~g}$ of seed powder were subjected to Soxhlet apparatus for extraction using $500 \mathrm{ml}$ methanol. The process of extraction was carried out for $48 \mathrm{~h}$. The extracts were concentrated by vacuum evaporator. Dried extract were used for further studies. The crude $T$. ammi extract were qualitatively screened to determine the presence of bioactive compounds as per the standard tests described by Kaur and co-workers [15], Trease and Evans [16].

\section{Isolation and characterization}

The crude methanolic extract was subjected to silica gel column chromatography (SGCC) for purification of thymol as previously described [17]. $1 \mathrm{~g}$ of the residue was subjected to silica gel column with Toluene: Ethyl acetate as eluent in the ratio of 9.7:0.3. The eluted fractions were collected in different test tubes based on their colouration into 9 fractions (fractions 1-9). The residues in the column were washed out with methanol. All the collected fractions from the silica gel column were spotted onpre-coated Thin Layer chromatography (TLC) plates with silica gel Gas explained by Skoog et al. [18]. It was then kept in previously saturated developing chamber containing mobile phase (Toluene:Ethyl acetate), and allowed to run $3 / 4$ th height of the plate. The developed plate was removed and air dried. Plate was observed under UV light in a chamber and the spots were identified. Retention Factor (Rf) values were determined by using the following formula,

Retention Factor $(\mathrm{Rf})=$ Distance traveled by solute/Distance traveled by solvent

\section{Gas Chromatography-Mass Spectrometry (GC-MS)}

The samples were subjected for analysis using GC-MS-QP2010-P (Shimadzu) equipped with Quadra pole detector and split injection system. The GC was fitted with a ZP-624 capillary column $(30 \mathrm{~mm} \times$ $1.4 \mathrm{~mm}$, film thickness $0.25 \mu \mathrm{m}$ ). The temperature programmed were as follows: injector temperature $220^{\circ} \mathrm{C}$, initial oven temperature at $50^{\circ} \mathrm{C}$ for $2 \mathrm{~min}$, then rise to $250^{\circ} \mathrm{C}$ at the rate of $10^{\circ} \mathrm{C} / \mathrm{min}$ for $25 \mathrm{~min}$, transfer line temperature $220^{\circ} \mathrm{C}$. Helium was used as carrier gas at 35.6
$\mathrm{kPa}$ pressure with flow $2.5 \mathrm{ml} / \mathrm{min}$ and electronic pressure control being kept on. The EM voltage was $952.9 \mathrm{~V}$ with lower and upper mass limits set at 30 and $350 \mathrm{~m} / \mathrm{z}$. Samples were dissolved in $\mathrm{n}$-hexane and injected automatically. MS spectra of separated compounds were compared with Wiley7 Nist 05 mass spectral database.

\section{High Performance Liquid Chromatographic (HPLC) Analysis}

An isocratic HPLC method was employed to determination major active phytoconstituents in T. ammi extract. The reversed phase (C8) analytical column (Phenomenex) (Dimension: $150 \times 4.6 \mathrm{~mm}$ and Pore size: $5 \mu \mathrm{m}$ ) at the flow rate of $1.5 \mathrm{~mL} / \mathrm{min}$ at $50^{\circ} \mathrm{C}$ were used for the analysis. Both crude extract of T. ammi and the fractions collected obtained from Silica gel column were dissolved in methanol and analyzed by HPLC fitted with PDA detector at $272 \mathrm{~nm}$.

\section{Screening for anti-bacterial activity}

The anti-bacterial activity of the crude extract and the isolated thymol was carried out by Disc diffusion and Agar well diffusion methods respectively, against both Gram positive bacteria namely Bacillus subtilis, Streptococcus pyogenes and Methicillin Resistance Staphylococcus aureus (MRSA) and Gram negative bacteria namely Pseudomonas spp., Klebsiella spp. and Escherichia coli was carried out. The bacterial strains were purchased from MTCC, IMTECH, Chandigarh. Ampicillin $(10 \mathrm{mg} / \mathrm{ml})$ was used as standard control as demonstrated by Bauer and Kirby [19]. The stock culture of each bacteria used were sub-cultured at $37^{\circ} \mathrm{C}$ for $24 \mathrm{~h}$.

\section{Evaluation of anti-oxidant activity}

The evaluation of the anti-oxidant potential of the isolated thymol to scavenge 2,2-diphenyl-1-picrylhydrazyl (DPPH) free radicals was assessed by the standard colorimetric method as described by Mensor [20]. DPPH is a stable free radical, which changes its colour from violet to yellow upon reduction by the process of electron donation. Thymol, converts it to 1,1-diphenyl-2-(2, 4, 6-trinitophenyl) hydrazine. The scavenging potential of the thymol can thus be determined by their degree of discolouration to yellow.

Additionally we evaluated the anti-oxidant ability of thymol in scavenging the Hydrogen peroxide $\left(\mathrm{H}_{2} \mathrm{O}_{2}\right)$ free radicals. A total of $4 \mathrm{ml}$ of $(1.25-10 \mu \mathrm{l} / \mathrm{ml})$ thymol was added to $0.6 \mathrm{ml}$ of hydrogen peroxide solution $(4 \mathrm{mM})$ in phosphate buffer $(0.1 \mathrm{M}$ and $\mathrm{pH}$ 7.4). After incubating for $10 \mathrm{~min}$ at $37^{\circ} \mathrm{C}$, the absorbance at $230 \mathrm{~nm}$ was measured. Corresponding blanks were taken. The experiment was performed in triplicate. The absorbance of phosphate buffer as control was measured at $230 \mathrm{~nm}$. Hydrogen peroxide produces hydroxyl radicals in cells. Scavenging of these radicals is seen by the decrease in absorbance at $230 \mathrm{~nm}$ with increasing concentration of the test sample. The scavenging effect (\%) was measured using the formula,

$\mathrm{H}_{2} \mathrm{O}_{2}$ radical scavenging activity $(\%)=[($ Abs control-Abs sample)/Abs control] X 100

\section{In-vitro Hepatoprotective activity}

\section{Cell culture}

Normal WRL-68 Liver cell line (ATCC. No: CL-48) was purchased from the National Centre for Cell Sciences (NCCS), Pune. These cells 
Citation: Nathan AA, Balakrishnan AS (2017) In-vitro Evaluation of Thymol Derived from Trachyspermum ammi Against Acetaminophen Induced Hepatotoxicity Towards Lymphatic Filariasis Therapeutics. J Bacteriol Parasitol 8: 322. doi:10.4172/2155-9597.1000322

Page 3 of 8

were grown in Dulbecco's Modified Eagles medium (DMEM) with high glucose and were cultured with $10 \%$ fetal bovine serum (FBS) and 1X Antibiotic Antimycotic solution (containing penicillin, streptomycin and amphotercin-B). The cultures were maintained at $37^{\circ} \mathrm{C}, 5 \% \mathrm{CO}_{2}$ and sub-cultured periodically using $0.25 \%$ TrypsinEDTA solution.

\section{MTT assay}

The MTT assay is a simple non-radioactive colorimetric assay used to directly measure cell proliferation or viability and indirectly cell toxicity. The MTT assay relies on the mitochondrial activity of cells thus serves as a biomarker of cell metabolism. To determine cell viability and proliferation, the WRL-68 cells were seeded at a density of $1 \times 10^{4}$ cells / well in a 96-well plate at $37^{\circ} \mathrm{C}$ in $5 \% \mathrm{CO}_{2}$ and grown for $24 \mathrm{~h}$. At $75-80 \%$ confluency, cells were treated in four different conditions for $24 \mathrm{~h}$ at $37^{\circ} \mathrm{C}$. 1) Cells treated only with paracetamol in various concentrations $(25,50,100,250$ and $500 \mu \mathrm{g} / \mathrm{ml})$ in order to determine the half lethal concentration $\left.\left(\mathrm{LC}_{50}\right), 2\right)$. Cells treated only with thymol in the same concentrations as paracetamol; to determine the half maximum effective concentration $\left.\left(\mathrm{EC}_{50}\right), 3\right)$. Cells treated in combination, paracetamol followed by thymol and 4). Cells without any treatments act as negative control. After $24 \mathrm{~h}$ treatment, culture media were removed and collected accordingly. Fresh medium $(100 \mu \mathrm{l})$ was added along with MTT dye $(10 \mu \mathrm{l})(5 \mathrm{mg} / \mathrm{ml}$ in phosphate buffer $\mathrm{pH}$ 7.4) and incubated for $4 \mathrm{~h}$ at $37^{\circ} \mathrm{C}$ in $5 \% \mathrm{CO}_{2}$. The medium was removed and the formazan crystals were solubilized with DMSO (200 $\mu \mathrm{l})$. The absorbance of each well was read on a micro plate reader at $575 \mathrm{~nm}$. The relative cell viability (\%) related to control wells containing cell culture medium without any treatment was calculated by $[\mathrm{A}]$ test $/[\mathrm{A}]$ control $\times 100$.

\section{Lactate dehydrogenase (LDH) assay}

Lactate dehydrogenase is an oxido-reductase enzyme present in almost all organisms. Cells release LDH into the blood circulation (invivo) or into culture supernatant (in-vitro settings) when exposed themselves to any injurious stimuli or cells undergoing death. In this colorimetric $\mathrm{LDH}$ quantification assay, $\mathrm{LDH}$ reduces NAD to NADH, which then interacts with a specific probe to produce a colour which can be read at $\lambda \max =450 \mathrm{~nm}$.

\section{Trypan blue exclusion assay}

Trypan Blue assay was employed to further confirm the cell viability of WRL-68 cells with and without various treatments. Live and intact cells excludes the uptake of dye whereas, cells with damaged cell membrane took the dye and looks blue in colour.

\section{RT- PCR studies}

Semi-Quantitative PCR was performed in Veriti Thermal Cycler (Applied Biosystem) using Taq DNA Polymerase. Total RNA was isolated using TRI reagent. Reverse transcription was performed with $1 \mu \mathrm{g}$ DNAse treated RNA for 3 hours at $37^{\circ} \mathrm{C}$. The expression levels of IL- 6 and IL- 8 were quantified. Relative amount of target mRNAs were normalized to $\beta$-actin mRNA as internal control.

\section{Statistical analysis}

Data analyses were performed using Windows based Graph Pad PRISM (GraphPad Software, Version 6) and are expressed as mean \pm
SEM. We have employed Kolmogorov Smirnov's (KS) to determine the normality of distribution. Comparisons between two groups were performed by the unpaired parametric Student t-test or one way ANOVA, followed by Tukey's multiple comparison posttest. Statistical significance was accepted if the null hypothesis rejected at $\mathrm{p} \leq 0.05$.

\section{Results}

\section{Extraction yield and phytoconstituents}

The yields of methanol extracted crude residue from seeds of $T$. ammi and the active fraction after removal of solvent in rotary evaporator were around $15 \% \mathrm{w} / \mathrm{w}$ and $5 \% \mathrm{w} / \mathrm{w}$ respectively. The phytochemical screening of the methanolic seed extract of T. ammi showed that the seeds are rich in alkaloids, flavonoids, terpenoids, tannins and phenol. The presence of these various phytoconstituents was confirmed by standard phytochemical tests which were evident by the colour formation (Figures 1A-1D).

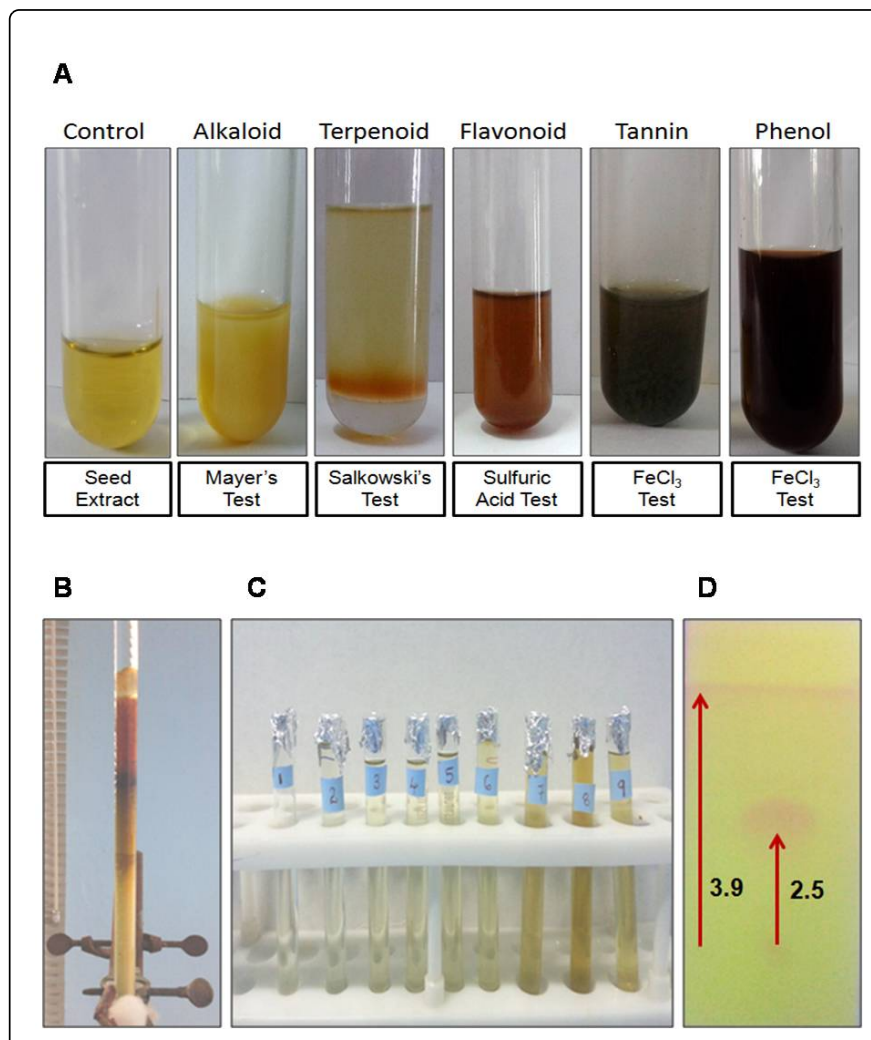

Figure 1: Phytochemical screening and separation. (A) Test tubes showing the results of confirmatory tests for various phytoconstituents present in the seed extract of Trachyspermum ammi and were identified based on the colour formations. (B) Separation of thymol using Silica gel column, (C) Test tube contains separated active fractions (1-9) and (D) Thin layer chromatographic plate showing the fraction migrated along the mobile phase Toluene: Ethyl acetate (9.7:0.3).

\section{Purification and characterization}

The SGCC was used to isolate and identify the active components in the plant extract and separated out the active fraction components 
Citation: Nathan AA, Balakrishnan AS (2017) In-vitro Evaluation of Thymol Derived from Trachyspermum ammi Against Acetaminophen Induced Hepatotoxicity Towards Lymphatic Filariasis Therapeutics. J Bacteriol Parasitol 8: 322. doi:10.4172/2155-9597.1000322

Page 4 of 8

based on the colour. In this study, $1 \mathrm{~g}$ of the crude extract was fractionated into fractions 1-9. Thin layer chromatography was employed to identify the specific component in the fractions based on the refractive index (Rf) value. TLC was performed to confirm the presence of thymol. Based on the Rf value, fractions 1-5 and 6-9 were pooled together. The results showed a spot with Rf value of 0.64 in TLC plate is identified as thymol, which was confirmed by comparing the standard thymol Rf value.

GC-MS analysis reported that there are eight active compounds were identified in the crude methanolic seed extract of $T$. ammi. The identified constituents were listed in the Table 1. GC-MS chromatogram shows the peak at the Retention Time (RT) $7.474 \mathrm{~min}^{-1}$ (Figures 2A-2C) indicates the presence of thymol (m/z-135.10) which was compared by the standard thymol peak. The reverse phase HPLC analysis confirms that the isolated compound was thymol by the chromatogram peak with a retention time nearly $6.18 \mathrm{~min}$ as previously reported.

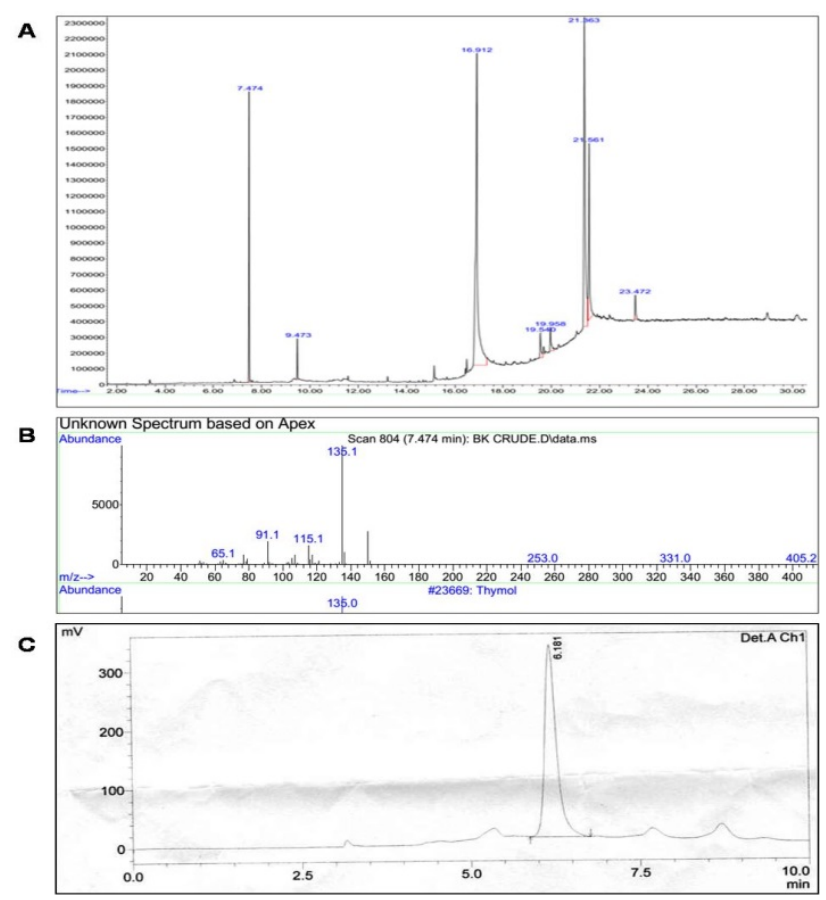

Figure 2: Characterization of phytoconstituents using analytical techniques. GC-MS chromatogram profile (A) showing various phytoconstituents present in the seed extract of Trachyspermum ammi and (B) Standard Thymol chromatogram. (C) Reverse phase HPLC chromatogram showing thymol peak with a retention time at $6.18 \mathrm{~min}$.

\section{Anti-bacterial activity}

The anti-bacterial activity of crude seed extract (Figures 3A and 3B) and isolated thymol against different bacterial strains shows zone of inhibition. A clear inhibition zone was formed around disc containing crude extract (disc diffusion) and well containing different concentrations of thymol (agar diffusion) with standard antibiotic, ampicillin as positive control. The diameter of the zones formed as result of the inhibited bacterial growth was measured using vernier calliper.

\begin{tabular}{|l|l|l|}
\hline Peak & Chemical compounds & $\begin{array}{l}\text { Retention } \\
\text { (RT) }\end{array}$ \\
\hline 1 & Thymol & 7.474 \\
\hline 2 & Apocynin & 9.50 \\
\hline 3 & Cadecadienoic acid & 17 \\
\hline 4 & 2,4-Dioxaspiro & 19.50 \\
\hline 5 & Octadecanoic acid & 20 \\
\hline 6 & 9-octadecanoic acid & 21.50 \\
\hline 7 & Durohydroquinone & 21.50 \\
\hline 8 & Benzo quinoline & 23.50 \\
\hline
\end{tabular}

Table 1: Major Phytoconstituents in T. ammi seeds crude extract.

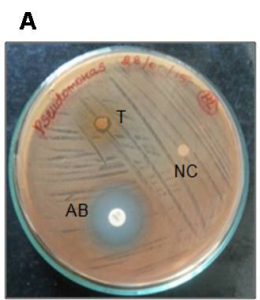

(Pseudomonas sp.)

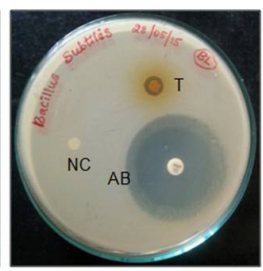

(Bacillus subtilis)

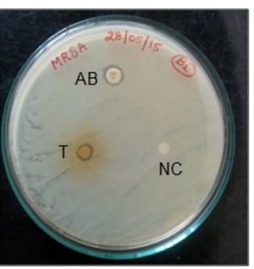

(MRSA)
B

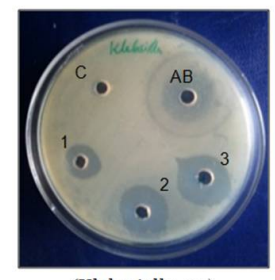

(Klebesiella sp.)

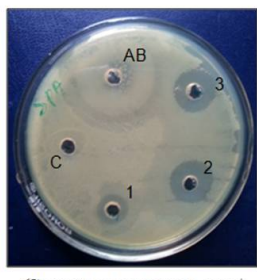

(Streptococcus pyogenes)

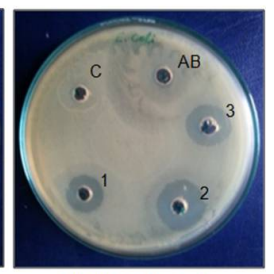

(Escherichia coli)
Figure 3: Screening of Anti-Bacterial activity of thymol. Representative images showing Mueller Hinton Agar plates to screen anti-bacterial activity of crude extract by Disc Diffusion method (A) and isolated thymol by Agar Well Diffusion method (B). Zone of Inhibition were observed against Gram positive bacterial strains in response to crude extract $(\mathrm{T})$ and no zone found around disc without any treatment (NC). Similarly zone of inhibition were observed against Gram negative bacterial strains in response to thymol at three different concentrations (1-3) and no zone found around control well (C). Ampicillin (10 mg/ml) was used as standard $(\mathrm{AB})$ control.

\section{Anti-oxidant activity}

Our data showed that thymol scavenges DPPH free radical in a dose dependent manner. Increasing the concentration of thymol (10-50 $\mu \mathrm{l} /$ $\mathrm{ml})$, increases the percentage scavenging activity $(\mathrm{p}=0.004)$, this is indicated by the intensities of colour change. The $\mathrm{H}_{2} \mathrm{O}_{2}$ radical 
Citation: Nathan AA, Balakrishnan AS (2017) In-vitro Evaluation of Thymol Derived from Trachyspermum ammi Against Acetaminophen Induced Hepatotoxicity Towards Lymphatic Filariasis Therapeutics. J Bacteriol Parasitol 8: 322. doi:10.4172/2155-9597.1000322

Page 5 of 8

scavenging ability of the thymol was higher than ascorbic acid at same concentration $(\mathrm{p}=0.008)$. The results were represented using line graph as shown in (Figures $4 \mathrm{~A}$ and $4 \mathrm{~B}$ ).

\section{A}

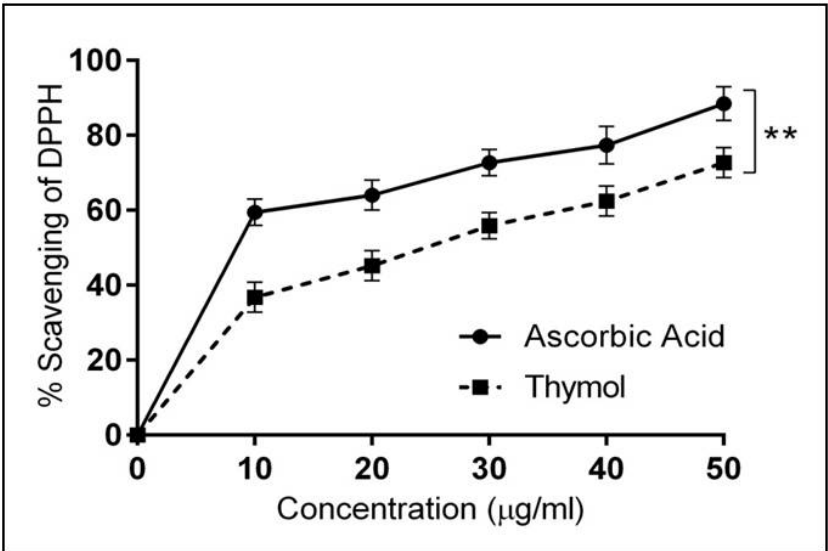

B

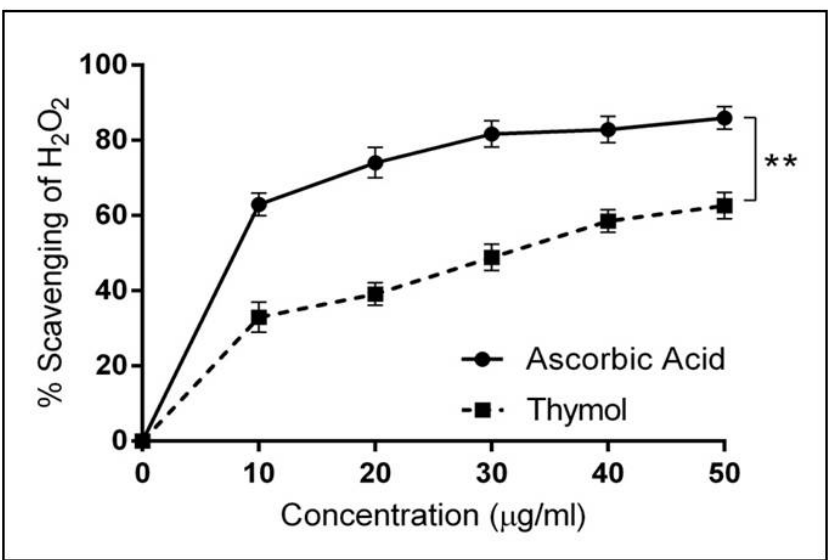

Figure 4: Evaluation of anti-oxidant activity of thymol. Line graph showing cumulative calorimetric data of Diphenyl Picryl Hydrazyl (DPPH) radical (A) and Hydrogen peroxide $\left(\mathrm{H}_{2} \mathrm{O}_{2}\right)$ radical (B) scavenging potential of thymol using ascorbic acid as reference standard. The absorbances were read out at $230 \mathrm{~nm}$. Data represented as mean \pm SEM of three separate experiments. ${ }^{* *}$ indicates $\mathrm{p}<0.01$ with reference standard.

\section{In-vitro hepatoprotective activity of thymol}

Cell viability and cytotoxicity of thymol and paracetamol at different concentrations $(25,50,100,250$ and $500 \mu \mathrm{g} / \mathrm{ml})$ was carried out in WRL-68 liver cell line at $24 \mathrm{~h}$, to determine the half maximum effective concentration $\left(\mathrm{EC}_{50}\right)$ and half lethal concentration $\left(\mathrm{LC}_{50}\right)$ value by MTT assay respectively. The percentage cell viability of WRL-68 cells was significantly decreased (from 80 to 20\%) with increasing concentrations of paracetamol as shown (Figures 5A-5D). At the same time, the cytotoxicity of WRL- 68 cells significantly increased (from 50 to 100\%) with increasing concentrations $(25,50,100,250$ and $500 \mu \mathrm{g} / \mathrm{ml})$ of paracetamol quantified in cell culture supernatant using LDH cytotoxicity assay. The $\mathrm{LC}_{50}$ value of paracetamol in WRL-68 cells was found to be $175 \mu \mathrm{g} / \mathrm{ml}$ (between 100 and $250 \mu \mathrm{g} / \mathrm{ml}$ ), whereas thymol does not show any toxicity in WRL-68 cells. Based on these observations we further evaluated the cell viability against paracetamol and thymol separately and in combination in two different concentrations (100 and $250 \mu \mathrm{g} / \mathrm{ml}$ ). We observed that percentage viability of WRL-68 cells was significantly decreased with increase in paracetamol concentrations $(\mathrm{p}=0.041$ and $\mathrm{p}=0.011)$. Interestingly, thymol at the same concentration recovers the decreased cellular viability by paracetamol within $24 \mathrm{~h}(\mathrm{p}=0.129$ and $\mathrm{p}=0.031)$. No significant differences were observed in the viability of thymol treatments.

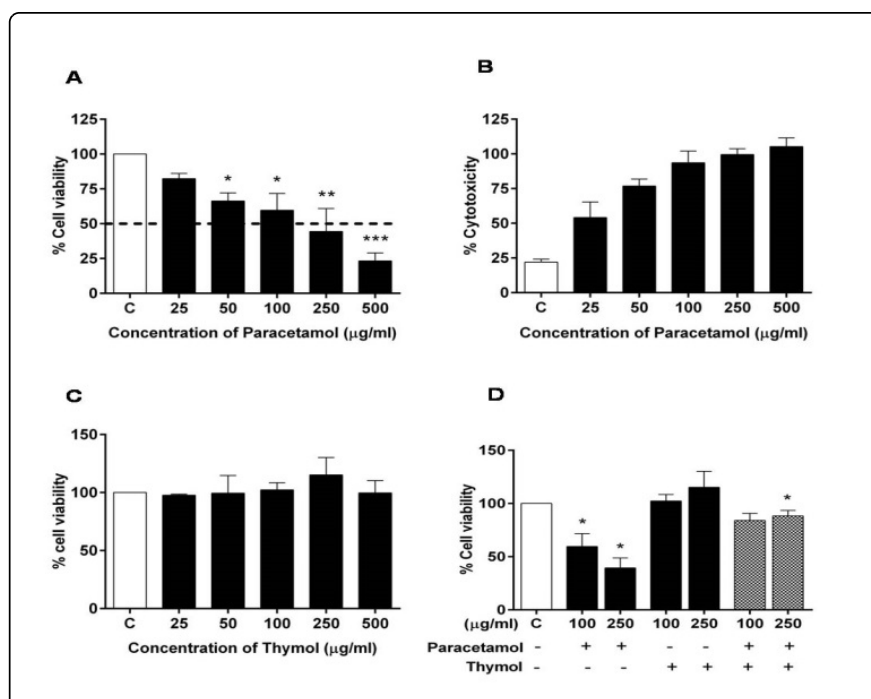

Figure 5: In-vitro Hepatoprotective potential of thymol. Cell viability and cytotoxicity of thymol were evaluated using WRL-68 liver cells. Bar graph shows \% cell viability (A) and (C) measured by MTT assay and \% cytotoxicity (B) measured by LDH assay with various concentrations of paracetamol and thymol treatments after $24 \mathrm{~h}$. Paracetamol reduced \% cell viability significantly, whereas thymol restored the cell viability as shown (D). Data represented as mean \pm SEM of three separate experiments. ${ }^{*} \mathrm{p}<0.05$ and ${ }^{*} \mathrm{p}<0.01$ $v s$. control (without any treatment).

\section{Thymol inhibits the expression of IL-6 and IL-8 in WRL-68 cells}

We quantified the expression of inflammatory cytokines namely IL-6 and IL-8 in WRL-68 liver cells in response to paracetamol treatment $(250 \mu \mathrm{g} / \mathrm{ml})$ after $24 \mathrm{~h}$. Parallely cells were incubated with the same concentrations of thymol alone and in combination with paracetamol in separate wells for $24 \mathrm{~h}$ at $37^{\circ} \mathrm{C}$. Cells without any treatments act as negative control. All the primers used for semiquantitative RT-PCR are given in the Table 2. We observed a significant increase in the expression of IL-6 $(p=0.046)$ in response to paracetamol treatments compared to the control group. Whereas cells treated with both paracetamol and thymol shows inhibited expression of IL-6 ( $\mathrm{p}=0.043)$ and IL-8 $(\mathrm{p}=0.048)$ which is as similar to cells without any treatments (Figures 6A and 6B). 
Citation: Nathan AA, Balakrishnan AS (2017) In-vitro Evaluation of Thymol Derived from Trachyspermum ammi Against Acetaminophen Induced Hepatotoxicity Towards Lymphatic Filariasis Therapeutics. J Bacteriol Parasitol 8: 322. doi:10.4172/2155-9597.1000322

Page 6 of 8

\begin{tabular}{|l|l|l|}
\hline Oligo & Forward Primers Sequence $\left(\mathbf{5}^{\prime} \mathbf{-} \mathbf{3}^{\prime} \mathbf{)}\right.$ & Reverse Primers Sequence $\left(\mathbf{5}^{\prime} \mathbf{-} \mathbf{3}^{\prime} \mathbf{)}\right.$ \\
\hline IL-6 & ATGAACTC CTTCTCCACAAGC & GTTTTCTGCCAGTGC CTCTTTG \\
\hline IL-8 & ATAAAGACATACTCCAAACCTTTCCAC & AAGCTTTACAATAATTTCTGTGTTGGC \\
\hline$\beta$-actin & CCTTGCACATGCCGGAG & GCACAGAGCCTCGCCTT \\
\hline
\end{tabular}

Table 2: List of RT-PCR primers used in the study.

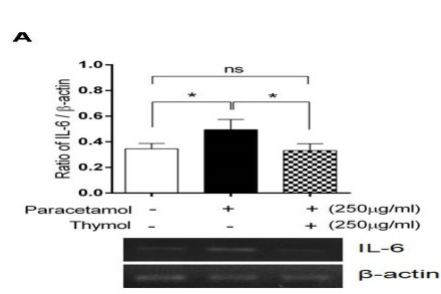

$\mathbf{B}$

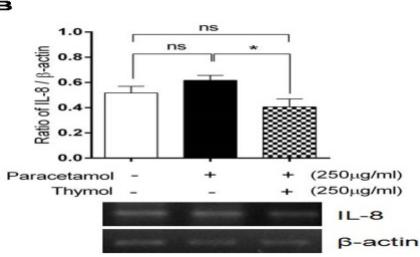

Figure 6: Semi-quantitative RT-PCR analysis. Bar graph shows the expression levels of IL-6 (A) and IL-8 (B) in the WRL-68 liver cells in response to paracetamol $(250 \mu \mathrm{g} / \mathrm{ml})$ and thymol $(250 \mu \mathrm{g} / \mathrm{ml})$ after $24 \mathrm{~h}$. Expression of IL-6 was increased significantly in paracetamol treatment confirming the induction of toxicity. At the same time, treatment of thymol inhibits the expression of IL- 6 and IL-8, as similar to the expression in cells without any treatment. Ratio of expression was normalized with $\beta$-actin. Data represented as mean \pm SEM of three separate experiments. ${ }^{*} \mathrm{p}<0.05 \mathrm{vs}$. control (without any treatment).

\section{Discussion}

Lymphatic filariasis is a painful and profoundly disfiguring disease caused by parasitic worms. Adult filarial worms dwell in the lymphatic vessels and eventually lead to chronic inflammation. Inflammatory damage induced by filarial parasites appears to be multifactorial and asymptomatic with endogenous parasite products, endosymbiotic bacteria, and host immune responses. Also stagnation of lymph fluid nourishes the growth of bacteria predominantly in the dermal cells and tissues which further fuels the complications. Current treatments using Diethylcarbamazine citrate (DEC) and Albendazole (ALZ) are promising and effective against microfilaria. Patients and physicians are in need for appropriate and efficient therapeutic agent which can combat the complications of chronic lymphedema in a multifunctional way.

Pharmacognostic studies pertaining to the therapeutics of dietary agents have shown that consumption of naturally available fruits, vegetables and spices lowers the incidence of inflammatory diseases. Since dietary agents found to possess many biologically active compounds those are ubiquitous in plants [21]. Thymol has been reported as one of the prime phytoconstituent in Trachyspermum ammi having macrofilaricidal activity against adult bovine filarial worm, Setaria digitata [22]. T. ammi is commonly known as 'Ajwain' or Bishop's weed, known for its good medicinal value in India. Hence in the present study we investigated the invaluable and incredible prowess of thymol extracted from methanolic fraction of $T$. ammi for its possible application in the treatment and management of LF. We studied the hepatoprotective role of thymol against paracetamol induced toxicity in normal WRL-68 liver cells; free radical and inflammatory cytokine mediated oxidative stress and inhibitory potential against infectious bacterial growth.

Thymol (2-isopropyl-5-methylphenol) is a natural mono-terpene and a phenolic derivative of cymene. It has been reported as one of the major essential oil in T. ammi. The natural ability of this phenolic rich thymol has high oxidative and bacterial aggression. Extensive studies proclaim the potential of thymol for both internal and external applications. Nieddu et al., described that oral administration of thymol was rapidly absorbed and slowly eliminated within $24 \mathrm{~h} \mathrm{[23].}$ Unabsorbed thymol was found in intestinal walls when taken in excess leaving no adverse effects. Santurio et al. demonstrated the antimicrobial activity of essential oil of thymol against $E$. coli strains of intestinal origin [24]. Gilani et al. evaluated the antimicrobial cream formulated with essential oil of $T$. ammi for dermal applications [25]. Recently Moon and Rhee examined the synergistic effect of thymol for its antimicrobial potential against major food-borne pathogens [26]. We observed a similar potential for crude extract of $T$. ammi and for thymol against Gram positive and Gram negative bacterial strains associated with filarial lymphedema. It was very evident that the zone of inhibition increased with corresponding increase in concentrations of thymol, indicated the anti-bacterial activity of thymol against infectious pathogens.

Over dose of paracetamol leads to liver toxicity was first observed and reported by Davidson et al. in two individuals. They observed eosinophilic degeneration along with chromatin condensation in the necrotic hepatocytes histopathologically [27]. Several other studies have reported that increased oxidative stress induced by reactive oxygen species (ROS) and reactive nitrogen (NO) species plays a major role in the recruitment of inflammatory cells and elevated levels of proinflammatory cytokines in individuals with paracetamol toxicity $[28,29]$. Consequent reports showed the ROS scavenging activity of $T$. ammi crude extract. Sreemoyee and colleagues [30] demonstrate that the essential oil of ajwain has good DPPH and moderate $\mathrm{H}_{2} \mathrm{O}_{2}$ radical scavenging activity. In the present study we attempted to determine the antioxidant potential of thymol in scavenging DPPH and $\mathrm{H}_{2} \mathrm{O}_{2}$ free radicals in-vitro. Our calorimetric assay result clearly indicates that scavenging potential of thymol directly proportional to the concentration which was further confirmed by the scavenging potential of ascorbic acid. In general, scavenging hydroxyl $(\mathrm{OH})$ and peroxynitrite (OONO) was an important antioxidant activity. Because these free radicals are highly reactive and can easily cross the cell 
membranes at specific sites, reacts with most biomolecules, causes tissue damage and cell death. Thus, removing $\mathrm{OH}$ and OONO were very important for the protection of living systems. The ability of thymol to quench hydroxyl radical seems directly related to the process of preventing lipid peroxidation. Thus thymol proved to be good antioxidant in suppressing oxidative stress by scavenging the reactive oxygen species.

The property of a drug or chemical or agent which protects liver cells from toxicity, injury or damage was described as hepatotonic. Alam et al., studied the in-vivo hepatoprotective activity of thymol against Carbon tetra chloride $\left(\mathrm{CCL}_{4}\right)$ induced toxicity in rodent model [31]. Gilani et al., investigated the in-vivo hepatoprotective action of aqueous-methanolic extract of Carum copticum in mice model against CCL4 and paracetamol induced liver damages [32]. We investigated the hepatoprotective potential of thymol against paracetamol induced toxicity in normal WRL-68 liver cell line because of its identical features as that of hepatocytes in primary culture and produce liver specific enzymes (ALT and AST). We examined cell viability, proliferation, sensitive marker (LDH) in liver injury and expression of cytokines (IL-6 and IL-8) in response to paracetamol and the action of thymol in these conditions. The results of our study were convincing and well correlated with the previously published in-vitro and in-vivo reports. We observed the percentage viability of WRL-68 cells was significantly decreased with increase in thymol concentrations (100 and $250 \mu \mathrm{g} / \mathrm{ml}$ ). Interestingly, thymol at the same concentration recovers the decreased cellular viability by paracetamol within $24 \mathrm{~h}$. No differences in the viability were observed in different thymol treatments. Indicating thymol promotes cell survival and proliferation in normal liver cells but may exert cytotoxicity in cancerous cells. Moreover influence the phenomenon of hepatic regeneration during liver injury and restoration of cell viability. Our RT-PCR data reconfirm the same findings that the expression levels of IL-6 and IL-8 were significantly elevated in cells treated with paracetamol, whereas cells treated with both paracetamol and thymol shows inhibited expression of IL-6 and IL-8 as similar to cells without any treatments. Suggesting thymol has the ability to attenuate the expression of these inflammatory cytokines which were in excess during acute liver injury. At the same time thymol protects liver from certain inflammatory insult, preserves liver function for its self-renewal. The results showed that the thymol offered maximum protection against hepatotoxicity caused by paracetamol.

\section{Conclusion}

In conclusion, our data suggests that Trachyspermum ammi (a good dietary agent) may be a promising natural source for thymol and its inherent, multifunctional therapeutic potential can be harnessed for the treatment and management of human lymphatic filariasis along with the drug of choice effectively.

\section{Acknowledgements}

The authors wish to acknowledge Department of Plant Biotechnology and Department of Molecular Microbiology, MKU for their technical assistance and support in plant screening, phytochemical analysis and anti-bacterial studies. Authors also wish to acknowledge University Science Instrumentation Centre (USIC), MKU for carrying out the analytical techniques. This study was partly supported by University Grants Commission-MRP (F.No. 39-289/2010-SR), Government of India and Madurai Kamaraj
University - Internal funding. AAN wish to acknowledge CSIR for Senior Research Fellowship.

\section{References}

1. Bennuru S, Nutman TB (2009) Lymphatics in human lymphatic filariasis: in vitro models of parasite induced lymphatic remodeling. Lymphat Res Biol 7: 215-219.

2. Babu S, Nutman TB (2012) Immunopathogenesis of lymphatic filarial disease. Semin Immunopathol 34: 847-861.

3. Shenoy RK (2008) Clinical and Pathological Aspects of Filarial Lymphedema and Its Management. Korean J Parasitol 46: 119-125.

4. Liu LX, Weller PF (1996) Drug therapy: Antiparasitic drugs. N Engl J Med 334: 1178-1184.

5. Anitha K, Shenoy RK (2001) Treatment of lymphatic filariasis: Current trends 67: 60-65.

6. Hinson JA, Roberts DW, James LP (2010) Mechanisms of Acetaminophen-Induced Liver Necrosis. Handb Exp Pharmacol 196: 369-405.

7. Pumford NR, Hinson JA, Benson RW, Roberts DW (1990) Immunoblot analysis of protein containing 3-(cystein-S-yl) acetaminophen adducts in serum and subcellular liver fractions from acetaminophen treated mice. Toxicol Appl Pharmacol 104: 521-532.

8. Jaeschke H, Gores GJ, Cederbaum AI, Hinson JA, Pessayre D, et al. (2002) Mechanisms of Hepatotoxicity. Toxicological Sciences 65: 166-176.

9. Bairwa R, Sodha RS, Rajawat BS (2012) Trachyspermum ammi. Pharmacogn Rev 6: 56-60.

10. Haquea R, Ansari SH, Kalam NA, Naquvi KJ (2012) Validated HPTLC analysis method for quantification of thymol content in trachyspermum ammi and polyherbal unani formulation arq zeera. Int $\mathrm{J}$ of Pharm Pharmac Sci 4: 478-482.

11. Babu S, Nutman TB (2014) Immunology of lymphatic filariasis. Parasite Immunol 36: 338-346.

12. Fielding CA, Jones GW, McLoughlin RM, McLeod L, Hammond VJ, et al. (2014) Interleukin-6 Signaling Drives Fibrosis in Unresolved Inflammation. Immunity 40: 40-50.

13. Li W, Liang X, Leu JI, Kovalovich K, Ciliberto G, et al. (2001) Global changes in interleukin-6-dependent gene expression patterns in mouse livers after partial hepatectomy. Hepatology 33: 1377-1386.

14. Li W, Liang X, Kellendonk C, Poli V, Taub R (2002) STAT3 contributes to the mitogenic response of hepatocytes during liver regeneration. J Biol Chem 277: 28411-28417.

15. Kaur GJ, Arora DS (2009) Antibacterial and phytochemical screening of Anethum graveolens, Foeniculum vulgare and Trachyspermum ammi. BMC Complement Altern Med 9: 30.

16. Trease GE, Evans WC (2002) Phytochemistry, Pharmacognosy 15th edn, Saunders Company (London). 304: 391-393.

17. He HP, Cai Y, Sun M, Corke H (2002) Extraction and purification of squalene from amaranthus grain. J Agric Food Chem 50: 368-372.

18. Skoog DA, West DM, Holler FJ, Crouch SR (2014) Fundamentals of Analytical Chemistry, 9th edn. Thomson-Brooks/Cole.

19. Bauer AW, Kirby WM, Sherris JC, Turck M (1966) Antibiotic susceptibility testing by a standardized single disk method. Am J Clin Pathol 45: 493-496.

20. Mensor LL, Menezes FS, Leitão GG, Reis AS, Santos TC, et al. (2001) Screening of Brazilian plant extracts for antioxidant activity by the use of DPPH free radical method. Phytother Res 15: 127-130.

21. Aggarwal BB, Shishodia S (2006) Molecular targets of dietary agents for prevention and therapy of cancer. Biochem Pharmacol 71: 1397-1421.

22. Mathew N, Bhattacharya SM, Perumal V, Muthuswamy K (2008) Antifilarial lead molecules isolated from Trachyspermum ammi. Molecules 13: 2156-2168.

23. Nieddu M, Rassu G, Boatto G, Bosi P, Trevisi P, et al. (2014) Improvement of thymol properties by complexation with cyclodextrins: In vitro and in vivo studies. Carbohydr Polym 102: 393-399. 
Citation: Nathan AA, Balakrishnan AS (2017) In-vitro Evaluation of Thymol Derived from Trachyspermum ammi Against Acetaminophen Induced Hepatotoxicity Towards Lymphatic Filariasis Therapeutics. J Bacteriol Parasitol 8: 322. doi:10.4172/2155-9597.1000322

Page 8 of 8

24. Santurio DF, Kunz FP, Zanette RA, Schlemmer KB, Fraton A, et al. (2014) Antimicrobial Activity of the Essential Oil of Thyme and of Thymol against Escherichia coli Strains. Acta Scientiae Veterinariae 42: 1234.

25. Gilani GR, Mahmood Z, Hussain M (2013) Preliminary evaluation of antimicrobial activity of cream formulated with essential oil of Trachyuspermum ammi. Pak J Pharm Sci 26: 893-896.

26. Moon H, Rhee MS (2016) Synergism between carvacrol or thymol increases the antimicrobial efficacy of soy sauce with no sensory impact. Int J Food Microbiol 217: 35-41.

27. Davidson DG, Eastham WN (1966) Acute liver necrosis following overdose of paracetamol. Br Med J 5512: 497-499.

28. Gardner CR, Laskin JD, Dambach DM, Sacco M, Durham SK, et al. (2002) Reduced hepatotoxicity of acetaminophen in mice lacking inducible nitric oxide synthase: potential role of tumor necrosis factoralpha and interleukin-10. Toxicol Appl Pharmacol 184: 27-36.
29. Cheung C, Yu AM, Ward JM, Krausz KW, Akiyama TE, et al. (2005) The cyp2e1-humanized transgenic mouse: role of cyp2e1 in acetaminophen hepatotoxicity. Drug Metab Dispos 33: 449-457.

30. Sreemoyee C, Goswami N, Kothari N (2013) Evaluation of antioxidant activity of essential oil from Ajwain (Trachyspermum ammi) seeds. Int J Pharm 7: 140-144.

31. Alam K, Nagi MN, Badary OA, Al-Shabanah OA, Al-Rikabi AC, et al. (1999) The protective action of thymol against carbon tetrachloride hepatotoxicity in mice. Pharmacol Res 40: 159-163.

32. Gilani AH, Jabeen Q, Ghayur MN, Janbaz KH, Akhtar MS (2005) Studies on the antihypertensive, antispasmodic, bronchodilator and hepatoprotective activities of the Carum copticum seed extract. J Ethnopharmacol 98: 127-135. 